\title{
Prevalence of Functional Gastrointestinal Disorders in Children and Adolescents
}

\author{
Meredith L. Lewis, BS, Olafur S. Palsson, PsyD, William E. Whitehead, PhD, and Miranda A. L. van Tilburg, PhD
}

Objectives To determine the prevalence of functional gastrointestinal (GI) disorders (FGIDs) in children and adolescents in a representative community sample of the US.

Study design The study recruited a general population sample of mothers $(n=949)$ of children and adolescents aged 4-18 years. Child and adolescent Gl symptoms were assessed using parental report through online questionnaires, including the Questionnaire on Pediatric Gastrointestinal Symptoms and the PedsQL4.0 Generic Core Scale. Parental GI symptoms, and demographic characteristics were also assessed. The data was used to determine prevalence of FGIDs.

Results Using Rome III criteria by parental report, $23.1 \%$ of children and adolescents qualified for at least 1 FGID. Functional constipation and abdominal migraine were the most common FGIDs. All 10 child/adolescent FGIDs occurred, except rumination. Significant prevalence differences were not found between sexes, except in functional constipation, which was more prevalent in males than females $(P=.022)$. There were no significant prevalence differences between racial or ethnic groups. Children who met criteria for an FGID had lower quality of life (median $=76.4$ ) than children who did not (median $=89.6 ; P<.001)$. Children were more likely to qualify for a FGID if their parent also qualified for a FGID $(P<.01)$.

Conclusions FGIDs are common in children and adolescents in the US. There are no significant differences in FGIDs between sex, race, or ethnic groups, except in functional constipation. There is overlap between parental and child FGID symptoms. Children with a FGID report a lower quality of life than healthy children. ( $J$ Pediatr 2016;177:39-43).

\footnotetext{
unctional gastrointestinal (GI) disorders (FGIDs) are common disorders characterized by recurring GI symptoms that cannot be attributed to structural or biochemical abnormalities. The Rome III diagnostic criteria for pediatric FGIDs distinguish 10 FGIDs. The prevalence by Rome criteria of these FGIDs has been addressed in multiple studies, and overall prevalence ranges between $12 \%$ and 29\% for all FGIDs combined. Most studies have used school samples, including the US, ${ }^{1,2}$ Germany, ${ }^{3}$ Panama, ${ }^{4}$ Ecuador, ${ }^{5}$ El Salvador, ${ }^{6}$ Colombia, ${ }^{7}$ Nigeria, ${ }^{8}$ Sri Lanka,,${ }^{9,10}$ and Japan. ${ }^{11}$ All these studies reported prevalence in limited geographical areas (eg, Chicago for one of the US studies ${ }^{8}$ ), limited age ranges (eg, adolescents in Japan ${ }^{11}$ ), and many focused exclusively on abdominal pain related disorders (eg, study in Germany, ${ }^{3}$ Sri Lanka ${ }^{9}$ ). There is still largely a lack of knowledge on less prevalent FGIDs like rumination.

There is a need for a large-scale prevalence study of all FGIDs in US children. Information including wider geographic areas and minority populations is necessary to describe the overall US population more thoroughly. Furthermore, inclusion of all child ages is important, as FGID prevalence has not been well described in younger age groups. More prevalence information will increase understanding of health issues and may provide guidance for management. For example, it may indicate the need to screen for and treat possibly underrecognized FGIDs. The current study attempted to provide a comprehensive picture of the prevalence of all FGIDs in children ages 4-18 years in a representative community sample of the US.
}

\section{Methods}

This study used a nationwide Internet survey in order to examine the prevalence of functional GI symptoms in children between ages 0-18 years.

FGID Functional GI disorder

GI Gastrointestinal

IBS Irritable bowel syndrome
From the University of North Carolina School of Medicine, Chapel Hill, NC

Supported by the Rome Foundation. However, the Rome Foundation did not have any role in study design, the collection, analysis, and interpretation of data, writing of the report, and the decision to submit the paper for publication. O.P., W.W., and M.VT. currently are part of the Rome Committee. The other authors declare no conflicts of interest. 
The subjects were mothers of children ages $0-18$ years old, who were recruited from all 50 states in the US, plus Washington DC and Puerto Rico. Cint USA, Inc (Lawrenceville, New Jersey; www.cint.com) provided the subjects from a pool of individuals who joined online panels to answer a variety of surveys (such as marketing, opinion polls, etc). Cint USA, Inc runs large panels of adults who have signed up to participate in a variety of research. Cint USA, Inc randomly sends e-mails to panel members and panel members decide if they would like to participate. Equal sex composition, age group distribution (infants, toddlers, children, adolescents), and racial/ethnic groups were recruited using quotabased sampling. We focus only on parents of children ages 4-18 years old. The data on infants can be found in a previous report. ${ }^{12}$

The study used mothers as subjects to provide a report about their child's symptoms attributable to the following considerations: (1) mothers are most commonly the primary individual in a household to communicate a child's symptoms to a physician; (2) mothers are more frequently than fathers the primary caregivers, and, therefore, more likely to have better awareness of a child's symptoms; and (3) other studies that have studied the overlap between parent and child symptoms have focused on mothers. ${ }^{13-15}$ We were not able to obtain data from the children themselves because of the nature of the recruitment methods.

Mothers were invited to complete a survey on "child health." The survey was not described as an investigation of GI symptoms to avoid selection bias. Parents read an online consent form and electronically accepted study enrollment. The parents were not asked any identifying information, and the survey was completely anonymous. Each mother completed a secure online survey conducted through Qualtrics software (Qualtrics, Washington, DC).

Each mother answered the entire survey about 1 child. The instructions asked mothers who had more than 1 child to answer all questions about the child whose name was first in alphabetical order. This study was approved by the Institutional Review Board of the University of North Carolina at Chapel Hill.

\section{Rome Questionnaires}

The Questionnaire on Pediatric Gastrointestinal SymptomsRome III Version is a validated questionnaire for child and adolescent FGIDs. ${ }^{16-18}$ The Parent-Report Form for children 4 years of age and older was used.

Mothers also completed a questionnaire about their own symptoms, using the Functional Bowel Module of the Rome III Questionnaire for Adults. ${ }^{19}$ Only the questions relating to irritable bowel syndrome (IBS), functional dyspepsia, functional constipation, and functional diarrhea were included (to limit participant burden).

\section{Quality of Life Questionnaire}

The PedsQL4.0 Generic Core Scale is a validated scale to measure quality of life in children ages 2 years and up. ${ }^{20}$ Separate parent-proxy scales were used for toddlers (ages 2-4 years), young children (ages 5-7 years), older children (ages 812 years), and teens (ages 13-18 years). The questionnaire includes separate subscales for physical, emotional, social, and school/daycare functioning and calculates a total score. ${ }^{20}$ Scores were transformed to a scale from 0-100, with higher scores indicating better quality of life.

\section{Demographics and Health}

Demographic questions included age, sex, and race/ethnicity of mother and child. It also included questions about marital status, common health problems, use of common medications, number of doctor's visits in the past 6 months, number of school/work absences in the past 6 months, household income, and state of residence.

\section{Analyses}

Inconsistent reporting and multiple entries were identified and excluded. Electronic cookies (small packets of computer code from the survey website placed on the respondent's computer) were used to ensure only 1 response from each computer device and to enable respondents to return to finish the survey within 24 hours if they left it incomplete. Respondents who provided inconsistent responses on 3 Rome questions that were repeated as a quality check, and respondents who showed other indiscriminate responding, were eliminated from the data set (eg, checking the same answer for a large number of variables, responses that were incompatible with each other such as inconsistent reporting of child age, etc.). Mothers who lived with their child less than one-half of the time were excluded because of increased likelihood of incomplete information. Mothers of children with inflammatory bowel disease or cancer were also excluded. There were no missing data because the Qualtrics survey required completion of every question.

Descriptive analyses were conducted to determine means and SDs as percentages of the sample. $\chi^{2}$ tests compared differences between subgroups for categorical variables, and $\mathrm{t}$ tests compared continuous variables.

\section{Results}

The study included 1447 mothers of children aged $0-18$ years old. Of these, 1127 subjects provided information about children ages 4-18 years, and 949 (84.2\%) of the responses about children aged 4-18 years were judged valid (provided consistent survey answers on quality/validity checks). Table I contains the general demographics and characteristics of the sample.

Mothers reported on the following existing physiciandiagnosed GI disorders in their children: constipation (1 participant-remained in study), dyspepsia (1 participant-remained in study), lactose intolerance (1 participant-remained in study, but did not qualify for any of the Rome diagnoses), fructose intolerance (no participants), celiac disease (no participants), chronic diarrhea (no participants), IBS/FAP (no participants), and gastroesophageal reflux disease/heartburn 
Table I. Sample characteristics

$\begin{array}{lcc}\mathbf{N}=\mathbf{9 4 9} \text { valid completers } & \text { Child } & \text { Mother } \\ \text { Sex } & & \\ \quad \text { Female } & 496(52.3 \%) & 949(100 \%) \\ \quad \text { Male } & 453(47.7 \%) & \\ \text { Age, } \mathbf{y} & & \\ \quad \text { Age range } & 4-18 & 22-73 \\ \quad \text { Mean age } & 10.6 & 40.0 \\ \quad \text { Age 4-6 } & 211(22.2 \%) & \\ \text { Age 7-9 } & 181(19.1 \%) & \\ \text { Age 10-12 } & 199(21.0 \%) & \\ \text { Age 13-15 } & 200(21.1 \%) & \\ \text { Age 16-18 } & 158(16.6 \%) & \\ \text { Race } & & \\ \text { Caucasian } & 633(66.7 \%) & 671(70.7 \%) \\ \text { African American } & 164(17.3 \%) & 165(17.4 \%) \\ \text { Asian } & 46(4.8 \%) & 49(5.2 \%) \\ \text { Ethnicity } & & \\ \text { Hispanic } & 178(18.8 \%) & 144(15.2 \%) \\ \text { Lives with mother 100\% } & 906(95.5 \%) & \\ \text { Married/cohabiting } & & 684(72.1 \%) \\ \text { Household income } & & \\ <\$ 25000 & & 157(16.5 \%) \\ \text { \$25 000-\$50 000 } & & 279(29.4 \%) \\ \text { \$50 000-\$100 000 } & & 123(13.6 \%) \\ >\$ 100000 & & 43(4.5 \%) \\ \text { Do not wish to disclose } & & \\ & & \end{array}$

(no participants). One child had a physician diagnosis of IBD and was excluded from the study.

\section{Rome Diagnoses}

The sample showed $23.1 \%$ of children qualified for at least 1 FGID by Rome III criteria (Table II). All 10 child/ adolescent FGIDs occurred, except rumination. Functional constipation and abdominal migraine were the most common FGIDs.

Significant differences in prevalence or type of FGIDs were not found between males and females, except for functional constipation, which was significantly more prevalent in males than females $(P=.022)$. There were no significant differences in prevalence or type of FGIDs between racial or ethnic groups (Tables III and IV; available at www.jpeds.com).

The prevalence of individual GI symptoms in children is reported in Table V (available at www.jpeds.com). The majority

Table II. FGID prevalence in children and parents

\begin{tabular}{|c|c|c|}
\hline & $\begin{array}{c}\text { Child/adolescent } \\
\text { prevalence }\end{array}$ & $\begin{array}{c}\text { Parent } \\
\text { prevalence }\end{array}$ \\
\hline FGID & $N=949$ & $\mathrm{~N}=949$ \\
\hline Any FGID & $219(23.1 \%)$ & $324(34.1 \%)$ \\
\hline Functional constipation & $122(12.9 \%)$ & $67(7.1 \%)$ \\
\hline Abdominal migraine & $87(9.2 \%)$ & $\mathrm{N} / \mathrm{A}$ \\
\hline Aerophagia & $41(4.3 \%)$ & N/A \\
\hline IBS & $27(2.8 \%)$ & $133(14.0 \%)$ \\
\hline Nonretentive fecal incontinence & $17(1.8 \%)$ & $\mathrm{N} / \mathrm{A}$ \\
\hline Cyclic vomiting syndrome & $10(1.1 \%)$ & $\mathrm{N} / \mathrm{A}$ \\
\hline Functional abdominal pain syndrome & $8(0.8 \%)$ & N/A \\
\hline Functional abdominal pain & $3(0.3 \%)$ & $\mathrm{N} / \mathrm{A}$ \\
\hline Functional dyspepsia & $2(0.2 \%)$ & $165(17.4 \%)$ \\
\hline Rumination & $0(0.0 \%)$ & $\mathrm{N} / \mathrm{A}$ \\
\hline Functional diarrhea & $\mathrm{N} / \mathrm{A}$ & $45(4.7 \%)$ \\
\hline
\end{tabular}

N/A, not applicable. of children had abdominal pain less than once a month, and 12 bowel movements a day. Of the mothers who participated in the study, 34.1\% qualified for a FGID, with functional dyspepsia and IBS being the most common (Table II).

\section{Quality of Life}

The quality of life data was examined for normality by the Shapiro-Wilkes test, which was significant $(P<.001)$. The Q-Qplot also showed deviations from normality (peaked data, kurtosis $=3.37$ ). Children with a FGID had lower quality of life scores (median $=76.4$, range $=0.0-100.0$ ) than children who did not meet the Rome III criteria for a FGID $($ median $=89.6$, range $=0.0-100.0)$, by Mann-Whitney test $(P<.001)$. Table VI (available at www.jpeds.com) shows further data regarding quality of life sub-scores and individual FGIDs.

\section{Parent-Child Overlap}

$\chi^{2}$ test showed that children were more likely (34\% vs $17 \%$; $P<.001)$ to have a FGID if their mother also qualified for a FGID. Table VII compares overlap between children with a specific FGID and mothers with the same FGID (ie, Children with IBS compared with mother's IBS qualification). Significant parent-child overlap was found specifically for IBS but not for functional constipation or dyspepsia.

Child-parent overlap was also found for specific symptoms. Children were more likely to suffer from abdominal pain at least once a week $(P<.01)$ and report hard stools $(P<.01)$ or loose stools $(P<.01)$ if mothers reported such symptoms as well.

\section{Discussion}

This study provides a comprehensive picture of the prevalence of FGIDs in a representative sample of children in the US. The sample included a significant proportion of minorities, who have been underrepresented in previous FGID prevalence research. In the population studied, almost onequarter $(23.1 \%)$ of children and adolescents qualified for least one FGID according to Rome III diagnoses.

This study found similar prevalence rates of IBS, ${ }^{2,7,9}$ aerophagia, ${ }^{21,22}$ and abdominal migraine ${ }^{2,7,10}$ as reported in previous studies. FAP and functional dyspepsia were reported with lower prevalence in this study than in previous studies, ${ }^{1,23}$ and cyclic vomiting syndrome and nonretentive fecal incontinence were more prevalent in this study compared with past research. ${ }^{7,10}$ The reasons for this are

Table VII. Parent-child overlap for FGID

$\begin{array}{lccr}\text { Child has any FGID } & 113(34.9 \%) & 106(17.0 \%) & <0.01 \\ \text { Child IBS } & 8(6.0 \%) & 19(2.3 \%) & 0.02 \\ \text { Child functional constipation } & 6(9.0 \%) & 116(13.2 \%) & 0.32 \\ \text { Child functional dyspepsia } & 0(0.0 \%) & 2(0.3 \%) & 0.52\end{array}$


unclear, although it may have been due to our use of parental report methodology, the sample being from the general community, because of differences in the specific questionnaires used, or regional/country differences between studies. Our study included a large sample across all US states that included significant proportions of minorities, and this may have influenced the proportion of reported FGIDs. The prevalence of rumination has been practically unknown, and it is notable that our large sample did not include a single case of a child who met diagnostic criteria for this disorder.

The FGID prevalence differences between race, ethnicity, and sex were not significant in children and adolescents in this sample. Race and ethnicity FGID prevalence differences have largely not been studied due to minimal minority inclusion in previous studies. One study reported FGIDs are common in African American girls but did not include a comparison group. ${ }^{22}$ In general, the prevalence of FGIDs, especially abdominal pain related disorders, has been reported to be higher in females than males. ${ }^{23-25}$ It is not clear why our data did not show a sex difference. Prevalence rates for individual disorders may have been too low for the least common FGIDs to detect significant sex differences.

FGIDs were associated with lower quality of life. Impaired quality of life can manifest in children as more school absences, more illness, and less desire for social interaction with friends. Children with these disorders are more vulnerable to developing pain and mental health problems later in life. ${ }^{26,27}$

We found a significant overlap in IBS in mothers and their children. The overlap between mothers and children may be both due to inheritance of genes and social factors such as maternal solicitous reactions to symptoms. ${ }^{28,29}$ Other factors, such as socioeconomic status, shared life experiences (eg, family stress or trauma), race, ethnicity, personality, and beliefs on pain and coping may also play a role in the overlap, and explain why FGIDs tend to run in families. ${ }^{13,23}$ This study did not collect information suited for examining these other factors.

The study also had several limitations. Although the large sample size and representation of demographic groups is well suited to give an idea of prevalence in children in the US general population, the fact that this was a community survey makes it impossible to exclude organic medical causes for reported symptoms. There is evidence that it is very unlikely to find a medical cause to explain most symptoms that fit criteria for FGIDs. ${ }^{30-32}$ However, it remains a variable that cannot be accounted for within community surveys. Furthermore, relying on parental rather than child report of symptoms is a limitation. Agreement between parent and child on the Questionnaire on Pediatric Gastrointestinal Symptoms-Rome III Version is low for certain disorders. ${ }^{33,34}$ Parent-reported FGID prevalence rates have been found to be lower than child report, ${ }^{2,35}$ and parents are often not aware of their (older) child's bowel symptoms. ${ }^{33}$ Parents may also be unaware of nonobservable symptoms. For example, rumination (in a more minor form, outside of children who are disabled) may occur in private or without parental awareness. ${ }^{36}$ This may contribute to the zero-prevalence of rumination found in this study.

Using online panels (cint.com) may create sources of bias, including sample bias as online questionnaires may limit accessibility to lower income individuals. ${ }^{37}$ Up to $20 \%$ of the US population under 65 years old does not have Internet access at home. ${ }^{37}$ Nonresponse rates may also lead to bias in the sample, although telephone questionnaires have similar or higher nonresponse rates. ${ }^{38,39}$ The possibility for sampling bias was reduced with purposeful sampling. Cint USA, Inc ensured a demographically balanced sample by directing the questionnaire to individuals of specific demographics.

In conclusion, the data collected in this study indicate that FGIDs are highly prevalent in US children and adolescents. Functional constipation and abdominal migraine are the most common of these disorders in children and adolescents. In addition, presence of FGIDs is associated with lower quality of life for children. Future longitudinal studies may help determine if these childhood and adolescence FGIDs persist and develop into adult FGIDs.

Submitted for publication Jan 25, 2016; last revision received Mar 23, 2016; accepted Apr 5, 2016.

Reprint requests: Miranda A. L. van Tilburg, PhD, Center for Functional Gl and Motility Disorders, University of North Carolina School of Medicine, 4106 Bioinformatics Building, Campus Box 7080, Chapel Hill, NC 27599-7080. E-mail: Tilburg@med.unc.edu

\section{References}

1. Hyams JS, Burke G, Davis PM, Rzepski B, Andrulonis PA. Abdominal pain and irritable bowel syndrome in adolescents: a community-based study. J Pediatr 1996;129:220-6.

2. Saps M, Adams P, Bonilla S, Chogle A, Nichols-Vinueza D. Parental report of abdominal pain and abdominal pain-related functional gastrointestinal disorders from a community survey. J Pediatr Gastroenterol Nutr 2012;55:707-10.

3. Gulewitsch MD, Enck P, Schwille-Kiuntke J, Weimer K, Schlarb AA. Rome III criteria in parents' hands: pain-related functional gastrointestinal disorders in community children and associations with somatic complaints and mental health. Eur J Gastroenterol Hepatol 2013;25: 1223-9.

4. Lu PL, Saps M, Chanis RA, Velasco-Benitez CA. The prevalence of functional gastrointestinal disorders in children in Panama: a school-based study. Acta Paediatr 2016;105:e232-6.

5. Jativa E, Velasco-Benitez CA, Koppen IJ, Cabezas ZJ, Saps M. Prevalence of functional gastrointestinal disorders in school children in Ecuador. J Pediatr Gastroenterol Nutr 2016 Jan 14. [Epub ahead of print].

6. Zablah R, Velasco-Benitez CA, Merlos I, Bonilla S, Saps M. Prevalence of functional gastrointestinal disorders in school-aged children in El Salvador. Rev Gastroenterol Mex 2015;80:186-91.

7. Saps M, Nichols-Vinueza DX, Rosen JM, Velasco-Benitez CA. Prevalence of functional gastrointestinal disorders in Colombian school children. J Pediatr 2014;164:542-5.

8. Udoh E, Devanarayana NM, Rajindrajith S, Meremikwu M, Benninga MA. Abdominal pain predominant functional gastrointestinal disorders in adolescent Nigerians. J Pediatr Gastroenterol Nutr 2016;62: 588-93.

9. Devanarayana NM, Mettananda S, Liyanarachchi C, Nanayakkara N, Mendis N, Perera N, et al. Abdominal pain-predominant functional gastrointestinal diseases in children and adolescents: prevalence, symptomatology, and association with emotional stress. J Pediatr Gastroenterol Nutr 2011;53:659-65. 
10. Devanarayana NM, Adhikari C, Pannala W, Rajindrajith S. Prevalence of functional gastrointestinal diseases in a cohort of Sri Lankan adolescents: comparison between Rome II and Rome III criteria. J Trop Pediatr 2011; 57:34-9.

11. Sagawa T, Okamura S, Kakizaki S, Zhang Y, Morita K, Mori M. Functional gastrointestinal disorders in adolescents and quality of school life. J Gastroenterol Hepatol 2013;28:285-90.

12. van Tilburg MA, Hyman PE, Walker L, Rouster A, Palsson OS, Kim SM, et al. Prevalence of functional gastrointestinal disorders in infants and toddlers. J Pediatr 2015;166:684-9.

13. van Tilburg MA, Levy RL, Walker LS, Von Korff M, Feld LD, Garner M, et al. Psychosocial mechanisms for the transmission of somatic symptoms from parents to children. World J Gastroenterol 2015;21:5532-41.

14. Levy RL, Whitehead WE, Walker LS, Von Korff M, Feld AD, Garner M, Christie D. Increased somatic complaints and health-care utilization in children: effects of parent IBS status and parent response to gastrointestinal symptoms. Am J Gastroenterol 2004;99:2442-51.

15. Campo JV, Bridge J, Lucas A, Savorelli S, Walker L, Di Lorenzo C, et al. Physical and emotional health of mothers of youth with functional abdominal pain. Arch Pediatr Adolesc Med 2007;161:131-7.

16. Caplan A, Walker L, Rasquin A. Validation of the pediatric Rome II criteria for functional gastrointestinal disorders using the questionnaire on pediatric gastrointestinal symptoms. J Pediatr Gastroenterol Nutr 2005;41:305-16.

17. Caplan A, Walker L, Rasquin A. Development and preliminary validation of the questionnaire on pediatric gastrointestinal symptoms to assess functional gastrointestinal disorders in children and adolescents. J Pediatr Gastroenterol Nutr 2005;41:296-304.

18. Walker LS, Caplan-Dover A, Rasquin-Weber A. Manual for the Questionnaire on Pediatric Gastrointestinal Symptoms (unpublished manuscript). Nashville, TN: Vanderbilt University School of Medicine; 2000.

19. Whitehead WE. Development and validation of the Rome III diagnostic questionnaire. In: Drossman DA, Corazziari E, Delvaux M, Spiller RC, Talley NJ, Thompson WG, et al., eds. Rome III: the functional gastrointestinal disorders. McLean, VA: Degnon Associates; 2006. p. 835-53.

20. Varni JW, Burwinkle TM, Seid M, Skarr D. ThePedsQL 4.0 as a pediatric population health measure: feasibility, reliability, and validity. Ambul Pediatr 2003;3:329-41.

21. Devanarayana NM, Rajindrajith S. Aerophagia among Sri Lankan schoolchildren: epidemiological patterns and symptom characteristics. J Pediatr Gastroenterol Nutr 2012;54:516-20.

22. Uc A, Hyman PE, Walker LS. Functional gastrointestinal disorders in African American children in primary care. J Pediatr Gastroenterol Nutr 2006;42:270-4.

23. Korterink JJ, Diederen K, Benninga MA, Tabbers MM. Epidemiology of pediatric functional abdominal pain disorders: a meta-analysis. PLoS One 2015;10:e126982.
24. Youssef NN, Murphy TG, Langseder AL, Rosh JR. Quality of life for children with functional abdominal pain: a comparison study of patients' and parents' perceptions. Pediatrics 2006;117:54-9.

25. Chang L. Review article: epidemiology and quality of life in functional gastrointestinal disorders. Aliment Pharmacol Ther 2004;20(Suppl 7): 31-9.

26. Horst S, Shelby G, Anderson J, Acra S, Polk DB, Saville BR, et al. Predicting persistence of functional abdominal pain from childhood into young adulthood. Clin Gastroenterol Hepatol 2014;12:2026-32.

27. Shelby GD, Shirkey KC, Sherman AL, Beck JE, Haman K, Shears AR, et al. Functional abdominal pain in childhood and long-term vulnerability to anxiety disorders. Pediatrics 2013;132:475-82.

28. Levy RL. Exploring the intergenerational transmission of illness behavior: from observations to experimental intervention. Ann Behav Med 2011;41:174-82.

29. van Tilburg MA, Zaki EA, Venkatesan T, Boles RG. Irritable bowel syndrome may be associated with maternal inheritance and mitochondrial DNA control region sequence variants. Dig Dis Sci 2014;59:1392-7.

30. Kocaay P, Egritas O, Dalgic B. Normal defecation pattern, frequency of constipation and factors related to constipation in Turkish children 0-6 years old. Turk J Gastroenterol 2011;22:369-75.

31. Dhroove G, Chogle A, Saps M. A million-dollar work-up for abdominal pain: is it worth it? J Pediatr Gastroenterol Nutr 2010;51:579-83.

32. Thornton GC, Goldacre MJ, Goldacre R, Howarth LJ. Diagnostic outcomes following childhood nonspecific abdominal pain: a recordlinkage study. Arch Dis Child 2015;101:305-9.

33. van Tilburg MA, Squires M, Blois-Martin N, Leiby A, Langseder A. Test of the child/adolescent Rome III criteria: agreement with physician diagnosis and daily symptoms. Neurogastroenterol Motil 2013;25. 302-e246.

34. Czyzewski DI, Lane MM, Weidler EM, Williams AE, Swank PR, Shulman RJ. The interpretation of Rome III criteria and method of assessment affect the irritable bowel syndrome classification of children. Aliment Pharmacol Ther 2011;33:403-11.

35. Schurman JV, Friesen CA, Danda CE, Andre L, Welchert E, Lavenbarg T, et al. Diagnosing functional abdominal pain with the Rome II criteria: parent, child, and clinician agreement. J Pediatr Gastroenterol Nutr 2005;41:291-5.

36. Chial HJ, Camilleri M, Williams DE, Litzinger K, Perrault J. Rumination syndrome in children and adolescents: diagnosis, treatment, and prognosis. Pediatrics 2003;111:158-62.

37. Bureau USC. Computer and Internet Access in the United States: 2012. http://www.census.gov/hhes/computer/publications/2012.html. Accessed January 20, 2016.

38. Willems P, Ossenbruggen R, Vonk TW. The effects of panel recruitment and management on research results. www.onderzoekpaleis.nl/... NOPVO2006-Barcelona-28112006.ppt. Accessed January 20, 2016.

39. Assessing the Representativeness of Public Opinion Surveys. Pew Research Center for the People and the Press. http://www.people-press.org/2012/ 05/15/assessing-the-representativeness-of-public-opinion-surveys/\#. Accessed November 5, 2014. 
Table III. Prevalence in FGID between sexes

\begin{tabular}{|c|c|c|c|}
\hline & $\begin{array}{l}\text { Proportion of } \\
\text { males }\end{array}$ & $\begin{array}{l}\text { Proportion of } \\
\text { females }\end{array}$ & \\
\hline & $N=453$ & $N=496$ & Significance \\
\hline Any FGID & $103(22.7 \%)$ & $116(23.4 \%)$ & 0.812 \\
\hline Functional constipation & $70(15.5 \%)$ & $52(10.5 \%)$ & 0.022 \\
\hline Abdominal migraine & $33(7.3 \%)$ & 54 (10.9\%) & 0.055 \\
\hline Aerophagia & $18(4.0 \%)$ & $23(4.6 \%)$ & 0.616 \\
\hline IBS & $9(2.0 \%)$ & $18(3.6 \%)$ & 0.129 \\
\hline $\begin{array}{l}\text { Nonretentive fecal } \\
\text { incontinence }\end{array}$ & $8(1.8 \%)$ & $9(1.8 \%)$ & 0.955 \\
\hline Cyclic vomiting syndrome & $7(1.5 \%)$ & $3(0.6 \%)$ & 0.156 \\
\hline $\begin{array}{l}\text { Functional abdominal pain } \\
\text { syndrome }\end{array}$ & $3(0.7 \%)$ & $5(1.0 \%)$ & 0.561 \\
\hline Functional abdominal pain & $1(0.2 \%)$ & $2(0.4 \%)$ & 0.617 \\
\hline Functional dyspepsia & $1(0.2 \%)$ & $1(0.2 \%)$ & 0.949 \\
\hline Rumination & $0(0.0 \%)$ & $0(0.0 \%)$ & $\mathrm{N} / \mathrm{A}$ \\
\hline
\end{tabular}

$N / A$, not applicable.

Table IV. Prevalence of FGID between racial croups

\begin{tabular}{|c|c|c|c|c|}
\hline & $\begin{array}{c}\begin{array}{c}\text { Proportion of Caucasian } \\
\text { children }\end{array} \\
\end{array}$ & $\begin{array}{c}\text { Proportion of African } \\
\text { American children } \\
\end{array}$ & $\begin{array}{c}\text { Portion of children } \\
\text { of other races } \\
\end{array}$ & \\
\hline & $N=633$ & $N=164$ & $N=145$ & Significance \\
\hline Any FGID & $150(23.7 \%)$ & $34(20.7 \%)$ & $33(22.8 \%)$ & 0.721 \\
\hline Functional constipation & $81(12.8 \%)$ & $15(9.1 \%)$ & $24(16.6 \%)$ & 0.149 \\
\hline Abdominal migraine & $57(9.0 \%)$ & $19(11.6 \%)$ & $11(7.6 \%)$ & 0.451 \\
\hline Aerophagia & $28(4.4 \%)$ & $8(4.9 \%)$ & $4(2.8 \%)$ & 0.607 \\
\hline IBS & $18(2.8 \%)$ & $6(3.7 \%)$ & $3(2.1 \%)$ & 0.704 \\
\hline Nonretentive fecal incontinence & $14(2.2 \%)$ & $2(1.2 \%)$ & $1(0.7 \%)$ & 0.382 \\
\hline Cyclic vomiting syndrome & $8(0.3 \%)$ & $0(0.0 \%)$ & $2(1.4 \%)$ & 0.342 \\
\hline Functional abdominal pain syndrome & $6(0.9 \%)$ & $0(0.0 \%)$ & $2(1.4 \%)$ & 0.375 \\
\hline Functional abdominal pain & $3(0.5 \%)$ & $0(0.0 \%)$ & $0(0.0 \%)$ & 0.480 \\
\hline Functional dyspepsia & $2(0.3 \%)$ & $0(0.0 \%)$ & $0(0.0 \%)$ & 0.613 \\
\hline Rumination & $0(0.0 \%)$ & $0(0.0 \%)$ & $0(0.0 \%)$ & $\mathrm{N} / \mathrm{A}$ \\
\hline
\end{tabular}


Table V. Prevalence of symptoms in children

Symptoms

\begin{tabular}{|c|c|c|c|c|c|c|c|c|c|c|c|}
\hline Symptoms & & & & & & iswer categories & & & & & \\
\hline Upper abdomen pain/discomfort & $\begin{array}{l}\text { Never } \\
75.1 \%\end{array}$ & $\begin{array}{c}<1 \times / \mathrm{mo} \\
11.7 \%\end{array}$ & $\begin{array}{c}1 \times / \mathrm{mo} \\
3.5 \%\end{array}$ & $\begin{array}{c}2-3 \times / \mathrm{mo} \\
4.4 \%\end{array}$ & $\begin{array}{l}1 \times / \text { wk } \\
1.4 \%\end{array}$ & $\begin{array}{c}2-3 \times / \text { wk } \\
1.7 \%\end{array}$ & $\begin{array}{c}\text { Most d } \\
1.3 \%\end{array}$ & $\begin{array}{c}\text { Every d } \\
0.5 \%\end{array}$ & \multicolumn{3}{|c|}{$\begin{array}{l}\text { Multiple times/d } \\
0.4 \%\end{array}$} \\
\hline Around belly button pain/discomfort & $\begin{array}{l}\text { Never } \\
57.3 \%\end{array}$ & $\begin{array}{c}<1 \times / \mathrm{mo} \\
22.5 \%\end{array}$ & $\begin{array}{c}1 \times / \mathrm{mo} \\
7.2 \%\end{array}$ & $\begin{array}{c}2-3 \times / \mathrm{mo} \\
9.3 \%\end{array}$ & $\begin{array}{l}1 \times / \text { wk } \\
1.8 \%\end{array}$ & $\begin{array}{c}2-3 \times / \mathrm{wk} \\
1.0 \%\end{array}$ & $\begin{array}{l}\text { Most d } \\
0.4 \%\end{array}$ & $\begin{array}{c}\text { Every d } \\
0.4 \%\end{array}$ & \multicolumn{3}{|c|}{$\begin{array}{l}\text { Multiple times/d } \\
0.1 \%\end{array}$} \\
\hline In past y, how often did food come back up into mouth? & $\begin{array}{l}\text { Never } \\
80.7 \%\end{array}$ & $\begin{array}{l}<1 \times / d \\
12.1 \%\end{array}$ & $\begin{array}{c}1 \times / \mathrm{mo} \\
2.4 \%\end{array}$ & $\begin{array}{c}2-3 \times / \mathrm{mo} \\
1.9 \%\end{array}$ & $\begin{array}{l}1 \times / \text { wk } \\
1.5 \%\end{array}$ & $\begin{array}{c}2-3 \times / \mathrm{wk} \\
0.4 \%\end{array}$ & $\begin{array}{l}\text { Most d } \\
0.4 \%\end{array}$ & $\begin{array}{c}\text { Every d } \\
0.3 \%\end{array}$ & \multicolumn{3}{|c|}{$\begin{array}{l}\text { Multiple times/d } \\
0.2 \%\end{array}$} \\
\hline How often does child have poops? & $\begin{array}{l}>3 \times / d \\
2.4 \%\end{array}$ & $\begin{array}{l}3 \times / d \\
3.5 \%\end{array}$ & $\begin{array}{c}2 \times / d \\
20.4 \%\end{array}$ & $\begin{array}{r}1 \times / d \\
51.4 \%\end{array}$ & $\begin{array}{l}6 / w k \\
4.0 \%\end{array}$ & $\begin{array}{c}5 \times / \text { wk } \\
5.5 \%\end{array}$ & $\begin{array}{c}4 \times / \text { wk } \\
4.3 \%\end{array}$ & $\begin{array}{c}3 \times / \mathrm{wk} \\
3.9 \%\end{array}$ & $\begin{array}{c}2 \times / \mathrm{wk} \\
1.2 \%\end{array}$ & $\begin{array}{c}1 \times / \text { wk } \\
1.0 \%\end{array}$ & $\begin{array}{c}>1 \times / w k \\
2.4 \%\end{array}$ \\
\hline What is child's poop usually like? & $\begin{array}{c}\text { Very Hard } \\
1.8 \%\end{array}$ & $\begin{array}{l}\text { Hard } \\
7.7 \%\end{array}$ & $\begin{array}{c}\text { Not Too Soft/Hard } \\
57.8 \%\end{array}$ & $\begin{array}{c}\text { Very Soft } \\
3.3 \%\end{array}$ & $\begin{array}{l}\text { Watery } \\
0.6 \%\end{array}$ & $\begin{array}{l}\text { Depends } \\
10.7 \%\end{array}$ & $\begin{array}{c}\text { Don't Know } \\
18.2 \%\end{array}$ & & & & \\
\hline In past $y$, how often did child vomit for $2+\mathrm{h}$ without stopping? & $\begin{array}{l}\text { Never } \\
80.7 \%\end{array}$ & $\begin{array}{c}1 \times / y \\
12.4 \%\end{array}$ & $\begin{array}{l}2 \times / y \\
4.5 \%\end{array}$ & $\begin{array}{l}3 \times / y \\
1.6 \%\end{array}$ & $\begin{array}{l}4+\times / y \\
0.8 \%\end{array}$ & & & & & & \\
\hline In past 2 mo, how often did child burp/belch repeatedly? & $\begin{array}{l}0 \text { Never } \\
58.3 \%\end{array}$ & $\begin{array}{c}1 \\
11.0 \%\end{array}$ & $\begin{array}{c}2 \\
10.0 \%\end{array}$ & $\begin{array}{c}3 \\
5.2 \%\end{array}$ & $\begin{array}{l}4 \\
3.2 \%\end{array}$ & $\begin{array}{c}5 \text { one-half the time } \\
5.3 \%\end{array}$ & $\begin{array}{c}6 \\
1.6 \%\end{array}$ & $\begin{array}{c}7 \\
1.6 \%\end{array}$ & $\begin{array}{c}8 \\
1.3 \%\end{array}$ & $\begin{array}{c}9 \\
1.1 \%\end{array}$ & $\begin{array}{c}10 \text { Always } \\
1.6 \%\end{array}$ \\
\hline In past 2 mo, how often did child swallow/gulp air? & $\begin{array}{c}0 \text { (Never) } \\
81.4 \%\end{array}$ & $\begin{array}{c}1 \\
6.4 \%\end{array}$ & $\begin{array}{c}2 \\
3.8 \%\end{array}$ & $\begin{array}{c}3 \\
1.2 \%\end{array}$ & $\begin{array}{l}4 \\
0.7 \%\end{array}$ & $\begin{array}{c}5 \text { (one-half the time) } \\
1.8 \%\end{array}$ & $\begin{array}{c}6 \\
1.4 \%\end{array}$ & $\begin{array}{c}7 \\
1.0 \%\end{array}$ & $\begin{array}{c}8 \\
1.0 \%\end{array}$ & $\begin{array}{c}9 \\
0.8 \%\end{array}$ & $\begin{array}{c}10 \text { (Always) } \\
0.5 \%\end{array}$ \\
\hline
\end{tabular}


Table VI. Child quality of life

\section{FGID}

QL physical median (range)

Without FGID (N = 730)

Any FGID ( $=219)$

Functional constipation $(\mathrm{N}=122)$

Abdominal migraine $(\mathrm{N}=87)$

Aerophagia $(\mathrm{N}=41)$

IBS $(\mathrm{N}=27)$

Nonretentive fecal incontinence $(\mathrm{N}=17)$

Cyclic vomiting syndrome $(\mathrm{N}=10)$

Functional abdominal pain syndrome $(\mathrm{N}=8)$

Functional abdominal pain $(\mathrm{N}=3)$

Functional dyspepsia $(\mathrm{N}=2)$

Rumination $(\mathrm{N}=\mathrm{O})$

$Q L$, quality of life.
$96.9(0.0-100.0)$

$87.5(0.0-100.0)$

$87.5(0.0-100.0)$

$87.5(9.4-100.0)$

$59.4(0.0-100.0)$

$71.9(9.3-100.0)$

$68.8(9.3-100.0)$

$46.9(12.5-100.0)$

$73.4(28.1-100.0)$

$84.4(81.3-87.5)$

$93.8(87.5-100.0)$

N/A
QL social

$95.0(0.0-100.0)$

$80.0(0.0-100.0)$

$80.0(0.0-100.0)$

$80.0(0.0-100.0)$

$50.0(0.0-100.0)$

$70.0(0.0-100.0)$

$70.0(0.0-100.0)$

$52.5(10.0-100.0)$

$80.0(40.0-95.0)$

$90.0(70.0-100.0)$

$100.0(100.0-100.0)$

$\mathrm{N} / \mathrm{A}$
QL emotional

$90.0(0.0-100.0)$

$70.0(0.0-100.0)$

$70.0(15.0-100.0)$

$70.0(0.0-100.0)$

$55.0(0.0-100.0)$

$50.0(0.0-97.9)$

$60.0(5.0-100.0)$

$57.5(10.0-85.0)$

$67.5(35.0-80.0)$

$55.0(40.0-86.5)$

$100.0(100.0-100.0)$

$\mathrm{N} / \mathrm{A}$
QL school

$90.0(0.0-100.0)$

$65.0(0.0-100.0)$

$70.0(0.0-100.0)$

$60.0(0.0-100.0)$

$50.0(0.0-100.0)$

$50.0(0.0-100.0)$

$55.0(0.0-100.0)$

$52.5(10.0-75.0)$

$65.0(30.0-95.0)$

83.3 (65.0-90.0)

$81.6(64.8-86.5)$

$100.0(100.0-100.0) \quad 98.4(96.9-100.0)$

N/A
QL total

89.6 (0.0-100.0)

$76.4(0.0-100.0)$

$6.3(0.0-100.0)$

$3.9(0.0-98.4)$

$63.4(5.3-97.9)$

$69.4(7.34-100.0)$

$51.0(10.6-86.1)$

73.5 (33.3-84.1)

$\mathrm{N} / \mathrm{A}$ 